\title{
Antioxidant Activity of Beetroot Powder on Alloxan Induced Diabetic Rats
}

\author{
Wafaa A. Refaat $^{1}$ and Doaa E. El-Nassag ${ }^{2}$ \\ ${ }^{1}$ Department of Nutrition and Food Science, Faculty of Home Economics, Menoufia University, Egypt \\ ${ }^{2}$ Department of Home Economics, Faculty of Specific Education, Alexandria University, Egypt
}

\section{Abstract:}

$\mathrm{D}$ iabetes mellitus (DM) is one of the most serious diseases that affect human health; DM is predicted to be the seventh leading cause of death by 2030 in the world. Diabetes particularly Type 2 is characterized by persistent production of reactive oxygen species (ROS) and generation of oxidative stress. Natural antioxidants have shown improving in treatment of diabetes. Therefore, this study was conducted to investigate the antioxidant activity of beetroot powder (BP) in different concentrations on alloxan - induced diabetic rats. Thirty adult male albino rats weighting $(160 \pm 10)$ were divided into 5 equal groups of 6 animals each, one was kept as a control -Ve group, while the other 4 groups were treated with alloxan $(150 \mathrm{mg} / \mathrm{kg}$ body weight) to induce diabetes mellitus. Group (2) were left as a control +Ve (diabetic rats) fed on normal diet at all experiment period (28 days), group 3,4 and 5 diabetic rats treated with $2 \%, 4 \%$ and $8 \%$ of beetroot powder, respectively. Liver enzymes activities, lipid profiles, antioxidant enzymes and glucose level in serum were examined. Significant increased in antioxidant enzymes activities of groups treated with beetroot powder in different concentrations. Treatment with BP with different concentration resulted in decreasing the rise of mean serum liver enzymes activities and prevented the rise of mean glucose concentrations in diabetic groups. On conclusion, the present study demonstrated the daily consumption of beetroot powder with meals could be potentially useful in improving hyperglycemia and diabetic complications.

Key words: Diabetes mellitus; Hyperglycemia; Beetroot, Lipid profiles, Liver enzymes; Antioxidant enzymes.

\section{Introduction}

Diabetes mellitus (DM) is not one disease, but rather is a heterogeneous group of syndromes characterized by an elevation of fasting blood glucose caused by a relative or absolute deficiency in insulin (Pamela et al., 2005), it is predicted to be the seventh leading cause of death by 2030 in the world, DM can be classified in two major types: Type I Diabetes 
(IDDM) and Type II Diabetes (NIDDM) (ADA, 2004). There are several factors that play great role in pathogenesis of diabetes such as hyperlipidemia and oxidative stress leading to high risk of complications (Kangralkar et al., 2010).

The release of reactive oxygen species (ROS) and generation of oxidative stress are considered critical factors for the pathogenesis of DM (WHO, 2010). DM is induced by oxidative stress (Elframawy and Rizk, 2011). Susceptible to oxidative stress leading to the development of diabetic complications (Lipinski, 2001 and Pham-Huy et al., 2008), through impairment of insulin reaction and increasing the complication incidence (Ullah et al., 2015) they concluded that natural antioxidants have shown to be prospective in the treatment of diabetes both type 1 and 2,therefore in recent years, the beetroot (Beta vulgaris) has attracted much attention as a health promoting functional foods as it delivers a high amount of bio accessible antioxidant and may be a cost effective and convenient method of increasing antioxidant status (Wotten-Bread and Rayan, 2011).

It is a root vegetable provides valuable essential nutrients such as carotenoids, nitrates, flavonoids, vitamins, minerals and water soluble pigment, all of which have numerous nutritional and health benefits (Panghal et al., 2017). High amount of bioactive compounds in beetroot pulp can be utilized as functional food source against many diseases like diabetes, cancer, cardiovascular disease and various other oxidative stresses induced chronic diseases (Chhikara et al., 2019). Also It is a rich source of nitrate and the betalain pigments, having potential antiviral, antioxidant and antimicrobial activities (Nisa $\boldsymbol{e t}$ al., 2015). Therefore, this study was conducted to investigate the antioxidant effect of feeding beetroots powder in different concentration and its protective role in ameliorating oxidative stress in alloxan- induced diabetic rats. 


\section{Materials and Methods}

\subsection{Chemicals}

All chemicals were analytical grade; vitamin and salt mixtures components used for rats feeding were purchased from Techno-Gene, Chemical Co., El Doki, Egypt. Casein was obtained from Morgan Chemical Co., Cairo, Egypt.

\subsection{Purchasing and preparation of raw materials}

The fresh red beet roots were purchased from the local vegetables market in Shebin El-Kom, Menoufia governorate, Egypt., and were stored at $4^{\circ} \mathrm{C}$ till using, the beetroots were washed thoroughly to remove the soil, the stems and the outer surfaces were peeled off and the pulp were shopped into thin slices to a thickness of $1 \mathrm{~mm}$ and dried in hot air oven at $40^{\circ} \mathrm{C}$. The dried beetroot slices were then ground using an electric grinder to obtain beetroot powder.

\subsection{Methods}

\subsubsection{Animals and experimental groups}

Thirty adult male albino rats weighting $(160 \pm 10)$ were divided into 5 equal groups 6 rats in each, one was kept as a control-Ve group, while the other 4 groups were treated with alloxan $(150 \mathrm{mg} / \mathrm{kg}$ body weight $)$ to induce diabetes mellitus according to the method described by Desai and Bhide (1985), group (2) were left as a control+Ve (diabetic rats) fed on normal diet all experiment period, group (3,4 and 5) diabetic rats treated with $2 \%$, $4 \%$ and $8 \%$ of beetroot powder, respectively.

\subsubsection{Blood samples collection}

At the end of experimental period all rats were anesthetized with diethyl ether after 12 hours fasting, blood samples were received from portal vein into clean dry centrifuge tubes in which blood samples left to clot at room temperature then centrifuged for 10 minutes at $3000 \mathrm{rpm}$ to separate the 
serum, all serum samples were stored frozen at $-20{ }^{\circ} \mathrm{C}$ for analysis (Malhotra, 2003).

\subsubsection{Biochemical analysis}

Different tested parameters in serum were determined using specific methods as follow: Serum glucose was estimated according to Rojas et al., (1999). Serum total cholesterol, triglyceride (TG) and high density lipoprotein (HDL-c) were determined by using methods of Allain et al., (1974), Fossati and Prencipe (1982) and Lopez-virella (1977), respectively. The determination of low density lipoprotein cholesterol (LDLc) and very low density lipoprotein cholesterol (VLDLc) were carried out according to the methods of Lee and Nieman (1996). Serum alanine aminotransferase (ALT) and aspartate aminotransferase (AST) were assayed by the methods of Moss and Herderson (1999).

\subsubsection{Antioxidant enzymes activity}

Glutathione peroxidase (GPx), superoxide dismutase (SOD), glutathione S-transferase (GST), catalase (CAT) were determined by Biodiagnostic Kit, Egypt.

\subsubsection{Statistical analyses}

The data were statistically analyzed using a computerized costat program by one-way ANOVA. The results are presented as mean \pm SD. Differences between treatments at $\mathrm{p} \leq 0.05$ were considered significant.

\section{Results and discussion}

\subsection{Effect of feeding beetroot powder in different concentrations on enzymatic antioxidant activity of alloxan- induced diabetic rats.}

The effect of feeding beetroot powder (BP) in different concentrations on antioxidant enzymes of alloxan- induced diabetic rats is shown in Table (1). Data indicated that there was a significant decrease in catalase (CAT), 
glutathione reductase (GSR), glutathione peroxidase (GSH-Px) and superoxide dismutase (SOD) activities in alloxan -induced diabetic rats compared with normal group and these findings were agreed with Maritim et al. (2003) who illustrated that diabetes induces alteration in activity of enzymes glutathione peroxidase and glutathione reductase, While the BP treated groups showed a significant increase in antioxidant enzymes compared with diabetic rats, so BP can increase antioxidant power and could be considered as an antioxidant factor by increasing glutathione level, these results were also agreed with Vulic et al. (2014) who concluded that the beetroot extracts appeared to maintain endogenous antioxidant activity at normal cellular concentrations following the oxidative insult, similar antioxidant effect has been reported with studies using beetroot juice (Kujawska et al., 2009).

According to Wotten - Beard and Ryan (2011) the beetroot juice shot (70 ml) provide a high amount of bio- accessible antioxidant and may be cost effective and convenient method of increasing antioxidant status. Slavov et al. (2013) revealed that antioxidant activity of BP is due to its high content of polyphenols, carotenoids and vitamins. Georgiev et al. (2010) and Račkauskiene et al. (2015) concluded that beet root as arich source of nitrate and betalain pigment has important antioxidant and natural colorant components. According to Nisa et al. (2015) they also confirmed that betanin pigment of beetroot has antioxidant and antimicrobial activities. So the results of this study concluded that BP can provide the body with bioactive compounds that have antioxidant activity against oxidative stress related diseases like DM. 
Table 1: Effect of feeding beetroot powder in different concentrations on enzymatic antioxidant activity of alloxan- induced diabetic rats

\begin{tabular}{|l|l|l|l|l|l|l|}
\hline \multicolumn{1}{|c|}{$\begin{array}{l}\text { Groups } \\
\text { Variables }\end{array}$} & $\begin{array}{l}\text { Negative } \\
\text { control }\end{array}$ & $\begin{array}{l}\text { Positive } \\
\text { control }\end{array}$ & 2\% B P & 4\% B P & 8\% B P & LSD \\
\hline GSH- Px (U/g) & $9.23^{\mathrm{e}} \pm 0.24$ & $20.43^{\mathrm{a}} \pm 0.96$ & $16.41^{\mathrm{b}} \pm 1.06$ & $13.91^{\mathrm{c}} \pm 0.62$ & $11.48^{\mathrm{d}_{ \pm}} \pm 0.72$ & 1.167 \\
\hline GR (U/g) & $8.48^{\mathrm{a}} \pm 0.26$ & $2.05^{\mathrm{e}} \pm 0.21$ & $4.12^{\mathrm{d}} \pm 0.59$ & $5.69^{\mathrm{c}} \pm 0.20$ & $7.76^{\mathrm{b}} \pm 0.08$ & 0.479 \\
\hline CAT (U/g) & $160.5^{\mathrm{b}} \pm 2.13$ & $126.2^{\mathrm{e}} \pm 3.28$ & $141.1^{\mathrm{d}} \pm 2.48$ & $153.8^{\mathrm{c}} \pm 4.39$ & $166.7^{\mathrm{a}} \pm 3.36$ & 4.857 \\
\hline SOD (U/g) & $3.19^{\mathrm{a}} \pm 0.14$ & $1.52^{\mathrm{e}} \pm 0.08$ & $1.85^{\mathrm{d}} \pm 0.08$ & $2.47^{\mathrm{c}} \pm 0.26$ & $2.79^{\mathrm{b}} \pm 0.17$ & 0.244 \\
\hline
\end{tabular}

Data are expressed as means $\pm \mathrm{SD}$; values within the same raw having superscripts letters are significantly different (P $\leq$ 0.05).B P: Beetroot powder; CAT: Catalase; GSR: Glutathione reductase; GSHPx:

Glutathione peroxidase; SOD: superoxide dismutase.

\subsection{Effect of beetroot powder in different concentrations on liver functions of diabetic rats}

Liver functions of alloxan induced diabetic-rats treated with different concentration of beetroot were shown in Table (2). from such data it could noticed that injection of alloxan caused a significant increase $(\mathrm{P} \leq 0.05)$ in alkaline phosphatase (ALP), alanine aminotransferase (ALT) and aspartate aminotransferase (AST) compared to normal control. Treatment with BP with different concentration resulted in decreasing the rise of mean serum AST, ALT and ALP activities .These results were agreed with Miraj (2016) who showed that red beet provides phytochemicals that stimulate immune system and liver protection. In this context, Krajka-Kuzniak et al. (2012) are agreed with our results, they reported that beetroot juice delivered by gavage ( $8 \mathrm{ml} / \mathrm{kg} . \mathrm{bw} /$ day) for 28 days protect against $\mathrm{N}$ nitrosodiethylamine- induced liver injury in ratsthrough decreasing the level of AST and ALT enzymes .According to Szaefer et al. (2014) who evaluated the effect of beetroot juice on DMBA-induced damage in liver of female Sprague-Dawley ratsand indicated that beetroot juiceresulted in reduce serum ALT activities .Beetroot also showed a significantly decrease in damaged effects on liver in mice subjected to dexamethasone (Abdul Bari et al ., 2018). 
Table 2: Effect of beetroot powder on liver functions of diabetic rats

\begin{tabular}{|c|c|c|c|c|c|c|}
\hline Groups & $\begin{array}{l}\text { Negative } \\
\text { control }\end{array}$ & $\begin{array}{l}\text { Positive } \\
\text { control }\end{array}$ & $2 \%$ B P & $4 \% \mathrm{~B} \mathrm{P}$ & $8 \%$ В P & LSD \\
\hline T.B (m/dl) & $0.59^{\mathrm{a}} \pm 0.23$ & $0.65^{\mathrm{a}} \pm 0.33$ & $0.64^{\mathrm{a}} \pm 0.17$ & $0.73^{\mathrm{a}} \pm 0.19$ & $0.56^{\mathrm{a}} \pm 0.17$ & 0.339 \\
\hline D.B (m/dl) & $0.14^{\mathrm{a}} \pm 0.04$ & $0.16^{\mathrm{a}} \pm 0.05$ & $0.15^{\mathrm{a}} \pm 0.03$ & $0.16^{\mathrm{a}} \pm 0.03$ & $0.14^{\mathrm{a}} \pm 0.04$ & 0.056 \\
\hline TP (g/dl) & $7.47^{\mathrm{a}} \pm 0.48$ & $7.09^{\mathrm{a}} \pm 0.36$ & $7.39^{\mathrm{a}} \pm 0.61$ & $7.20^{\mathrm{a}} \pm 0.70$ & $7.33^{\mathrm{a}} \pm 0.27$ & 0.771 \\
\hline ALB (g/dl) & $3.59^{\mathrm{a}} \pm 0.40$ & $3.56^{\mathrm{a}} \pm 0.18$ & $3.42^{\mathrm{a}} \pm 0.38$ & $3.42^{\mathrm{a}} \pm 0.18$ & $3.44^{\mathrm{a}} \pm 0.32$ & 0.465 \\
\hline $\mathrm{G}(\mathrm{g} / \mathrm{dl})$ & $3.85^{b} \pm 0.13$ & $3.54^{\mathrm{b}} \pm 0.42$ & $4.98^{\mathrm{a}} \pm 0.86$ & $3.78^{b} \pm 0.61$ & $3.90^{\mathrm{b}} \pm 0.17$ & 0.776 \\
\hline A/G (Ratio) & $0.79^{b} \pm 0.02$ & $1.02^{\mathrm{a}} \pm 0.14$ & $0.86^{\mathrm{b}} \pm 0.08$ & $0.92^{\mathrm{ab}} \pm 0.12$ & $0.89^{\mathrm{ab}} \pm 0.11$ & 0.157 \\
\hline ALP (U/L) & $121.7^{b} \pm 3.04$ & $143.6 \mathrm{a} \pm 3.66$ & $123.1^{b} \pm 3.80$ & $75.31^{d} \pm 3.09$ & $96.07^{c} \pm 3.20$ & 5.083 \\
\hline ALT (U/L) & $188.9^{\mathrm{a}} \pm 3.63$ & $125.0^{b} \pm 3.66$ & $84.82^{e} \pm 3.79$ & $99.06^{c} \pm 3.09$ & $91.24^{d} \pm 3.39$ & 5.305 \\
\hline AST (U/L) & $166.8^{\mathrm{c}} \pm 3.30$ & $242.8^{\mathrm{a}} \pm 3.68$ & $162.3^{c} \pm 3.37$ & $166.3^{c} \pm 3.79$ & $176.0^{\mathrm{b}} \pm 3.10$ & 5.211 \\
\hline
\end{tabular}

Values are expressed as means $\pm \mathrm{SD}$; mean in the same raw with different letters are significantly different $\mathrm{P} \leq$ 0.05. B P: Beetroot powder; T.B: Total bilirubin; D.B: Direct bilirubin; TP: Total protein; ALB: Albumin; ALP:Alkaline phosphatase; ALT:Alanine aminotransferase ; AST:Aspartate aminotransferase .

\subsection{Effect of beetroot powder in different concentrations on serum blood glucose of diabetic rats}

Data in Table (3) showed the effect of BP in different concentrations on serum blood glucose of alloxan induced diabeticrats. The results indicated that injection of alloxan caused a significant increase $(\mathrm{P} \leq 0.05)$ in serum glucose compared to normal control .BP treatment prevented the rise of mean glucose concentrations in diabetic groups. These results agreed with Kumar et al. (2016) who concluded that the ethanolic extract of beetroot (EEBT) possessed a potential anti-diabetic activity against streptozocin induced rats. According to Olumese and Oboh (2016) findings showed a glucose lowering effect of beetroot juice administration for six weeks to healthy subjects through inhibition of carbohydrate digestion and glucose absorption in the intestine, and the modulation of glucose release from the liver. The possible mode of action of serum glucose lowering activity of BP could be explained by increasing nitric 
oxide (NO). Jobgen et al. (2006) concluded that increasing NO may be an effective strategy to increase insulin sensitivity.

The same observation was reported by Sansbury and Hill, (2014) revealed that insulin resistance could be characterized by low nitric oxide (NO) bioavailability. Dietary nitrate supplementation in rodent models of diabetes improved insulin signaling and promoted glucose transporter 4 translocation (Jiang et al., 2014 and Khalifi et al., 2015). Postprandial glucose control in obese adult may be improved if dietary nitrates as beetroot juice are included as a part of their meal (Beals et al., 2017).

Table 3: Effect of beetroot powder in different concentrations on serum blood glucose of diabetic rats

\begin{tabular}{|c|c|c|c|c|c|c|}
\hline $\begin{array}{c}\text { Groups } \\
\text { Variables }\end{array}$ & $\begin{array}{c}\text { Negative } \\
\text { control }\end{array}$ & $\begin{array}{c}\text { Positive } \\
\text { control }\end{array}$ & $\mathbf{2 \%}$ B P & $\mathbf{4 \%}$ B P & $\mathbf{8 \%}$ B P & LSD \\
\hline $\begin{array}{c}\text { Glucose } \\
(\mathbf{m l} / \mathbf{d l})\end{array}$ & $186.0^{\mathrm{c}} \pm 3.56$ & $374.6^{\mathrm{a}} \pm 3.39$ & $307.6^{\mathrm{b}} \pm 3.49$ & $177.1^{\mathrm{d}} \pm 3.43$ & $114.4^{\mathrm{e}} \pm 3.27$ & $\mathbf{5 . 1 6 8}$ \\
\hline
\end{tabular}

Values are expressed as means \pm SD; mean in the same raw with different letters are significantly different $\mathrm{P} \leq 0.05$. B P: Beetroot powder.

\subsection{Effect of beetroot powder in different concentrations on serum Lipid profile of diabetic rats}

Values of serum lipid profiles parameters in control and BP treated diabetic groups were indicated in Table (4). It was found that alloxan injection significantly increased $(\mathrm{P} \leq 0.05)$ all lipid profile except high density lipoprotein (HDL) concentration, Table showed a significant decrease in total cholesterol (T.C), triglycerides (T.G) and low density lipoprotein (LDL) in BP treated diabetic groups compared with positive control group, while the opposite direction was observed for the HDL level.The obtained results were agreed with Clifford $\boldsymbol{e t}$ al. (2015) and Guldiken et al. (2016) elucidated that beetroot offered a vascular protective effects and could manage cardiovascular disease through reducing the bad cholesterol and oxidized LDL cholesterol .Beta-cyanin, 
the compound that gives beetroot its purplish red color, could help to reduce the oxidation of LDL - cholesterol (Coles and Clifton, 2012).

According to Ninfali and Angelino (2013) beetroot ingestion offered a beneficial physiological effect for atherosclerosis disease. This effect was due to its high content of betalains that reduced the homocysteine concentration and regulated the vascular homeostasis (Machha and Schechter, 2011). The inorganic nitrate $\left(\mathrm{NO}^{-}\right)$as an active ingredient in beetroot which is reduced by bacteria in salvia into nitric oxide (NO) might contribute in the prevention and treatment of cardiovascular disease (Lundberg et al., 2011 and Oliveria et al., 2016).

Table 4: Effect of beetroot powder in different concentrations on serum Lipid profile of diabetic rats

\begin{tabular}{|l|c|c|c|c|c|c||}
\hline $\begin{array}{c}\text { Groups } \\
\text { Variables }\end{array}$ & $\begin{array}{c}\text { Negative } \\
\text { control }\end{array}$ & $\begin{array}{c}\text { Positive } \\
\text { control }\end{array}$ & $\mathbf{2 \%} \mathbf{B} \mathbf{P}$ & $\mathbf{4 \%} \mathbf{B} \mathbf{P}$ & $\mathbf{8 \%} \mathbf{B} \mathbf{P}$ & LSD \\
\hline \hline T.C (mg/dl) & $89.58^{\mathrm{d}} \pm 3.17$ & $142.2^{\mathrm{a}} \pm 3.84$ & $106.0^{\mathrm{c}} \pm 3.60$ & $92.33^{\mathrm{d}} \pm 3.54$ & $128.7^{\mathrm{b}} \pm 3.83$ & 5.434 \\
\hline T.G (mg/dl) & $115.7^{\mathrm{b}} \pm 3.16$ & $104.9^{\mathrm{c}} \pm 3.39$ & $236.1^{\mathrm{a}} \pm 3.19$ & $67.41^{\mathrm{d}} \pm 3.75$ & $54.94^{\mathrm{e}} \pm 3.17$ & 5.034 \\
\hline HDL (mg/dl) & $36.83^{\mathrm{c}} \pm 3.11$ & $53.66^{\mathrm{a}} \pm 3.74$ & $14.01^{\mathrm{d}} \pm 3.32$ & $45.22^{\mathrm{b}} \pm 3.48$ & $44.14^{\mathrm{b}} \pm 3.80$ & 5.274 \\
\hline LDL (mg/dl) & $36.57^{\mathrm{c}} \pm 3.07$ & $66.22 \mathrm{~b} \pm 3.85$ & $28.77 \mathrm{~d} \pm 3.61$ & $26.28 \mathrm{~d} \pm 3.81$ & $82.57 \mathrm{a} \pm 3.90$ & 5.512 \\
\hline VLDL (mg/dl) & $23.93^{\mathrm{b}} \pm 3.44$ & $19.98^{\mathrm{b}} \pm 3.92$ & $46.46^{\mathrm{a}} \pm 3.69$ & $14.33^{\mathrm{c}} \pm 3.55$ & $13.38^{\mathrm{c}} \pm 3.21$ & 5.380 \\
\hline
\end{tabular}

Values are expressed as means $\pm \mathrm{SD}$; mean in the same raw with different letters are significantly different P $\leq 0.05$. B P: Beetroot powder; T.C: Total cholesterol; T.G: Triglycerides; HDL: High density lipoprotein; LDL: Low density lipoprotein; VLDL: Very Low density lipoprotein.

\section{Conclusion}

In conclusion, the obtained results supported our hypothesis that beetroot powder (BP) possesses antioxidant and antidiabetic activity as it contains several classes of phytochemicals and other compound such as NO that have the ability to inhibit diabetes complications through liver serum enzymes-lowering activity, enhancing the serum lipid profiles and 
increasing the level of antioxidant activity. Therefore, these findings recommended BP to be included in our daily diets, drinks and food supplementation.

\section{References}

Abdul Bari, M.A.; Albadri, M.H. and Hussein, F.H. (2018): The protective effects of beetroot against Dexamethasone induced damage in liver, kidney and Hyper-lipidemic effects in mice .Wipmr., 4(11):60-68.

ADA, American Diabetes Association (2004): Diagnosis and classification ofdiabetes. Diabetes Care 27 (1):5-10.

Allain, C. C; Richmond, N. and Rosechloy, P. (1974): Cholestrol enzymatic colorimetric test. Chem. Clin., 19 (20): 1350 - 1361.

Beals, W.J.; Binns, E.S.; Davis, L.J.; Giordano, R.G.;Klochak, L.A.; Paris, L.H.; Schweder, M.M.; Peltonen, L.G.; Scalzo, L.R. and Bell, C. (2017):Concurrent beet juice and carbohydrate ingestion influence on glucose tolerance in obese and non-obese adults. Journal of Nutrition and Metabolism, 2017:1-7.

Chhikara, N.; Kushwaha, K.; Sharma, P.; Gat, Y. and Panghal, A. (2019): Bioactive compounds of beetroot and utilization in food processing industry: A critical review, Food Chemistry Journal, 272:192-200.

Clifford, T.; Howatson, G.; West, J.D. and Stevenson, J.E. (2015): The potential benefits of red beetroot supplementation in health and disease. Nutrients, 7: 2801-2822.

Coles, L.M. and Clifton, P.M. (2012): Effect of beetroot juice on lowering blood pressure in free- living, disease free adults: arandomized, Placebo-controlled trial. Nutritional Journal, 11:106.

Desai, N.S. and Bhide, S.A. (1985): Hypoglycemic effect of Hantitonia Suaveolent.Indian .J.Med.,8: 86-91. 
El Faramawy, S.M. and Rizk, R.A.( 2011): Spectrophotometric studies onantioxidants-doped liposomes. J. Am. Sci., 7: 363-369.

Fossati, P. and Prencipe, L. (1982): Serum triglycerides determined calorimetrically with an enzyme that produces hydrogen peroxide. Clin. Chem., 28: 2077-2080.

Georgiev, V. G.; Weber, J.; Kneschke, E. M.; Denev, P. N.; Bley, T., and Pavlov, A. I. (2010): Antioxidant activity and phenolic content of betalain extracts from intact plants andhairy root cultures of the red beetroot Beta vulgaris cv. Detroit Dark Red. Plant Foods for Human Nutrition Journal, 65(2):105-111.

Guldiken, B.; Toydemir, G.; NurMemis, K.; Okur, S.; Boyacioglu, D. and Capanoglu, E.(2016): Home-processed red beetroot (Beta vulgaris L.) Products: Changes in anti-oxidant properties and bioaccessibility. International Journal of Molecular Sciences, 17:858.

Jiang, H.; Torregrossa, A, C.; Potts, A.; et al (2014): Dietary nitrate improves insulin signaling through GLUT4 translocation. Journal of Free Radical Biology and Medicine, 67:51-57.

Jobgen, W.S.; Fried, S.K.; Fu, W.J.; Meininger, C.J. and Wu, G. (2006): Regulatory role for the arginine-nitric oxide pathway in metabolism of energy substrate. Journal of Nutritional Biochemistry, 17(9):571-588.

Kangralkar, V.A.; Patil, S.D. and Bandivadekar, R.M. (2010): Oxidativestress and diabetes: a review. Int. J. Pharm. Appl. 1 (1): $38-45$.

Khalifi, S.; Rahimipour, A.; Jeddi, S.; Ghanbari, M.; Kazerouni,F. and Ghasemi,A.(2015):Dietary nitrate improves glucose tolerance and lipid profile in animal model of hyperglycemia .Journal of Nitric Oxide ,44:24-30. 
Krajka-Kuzniak, V.; Szaefer, H.; Ignatowicz, E.; Adamska, T. and Baer-Dubowska, W. (2012): Beetroot Juice protect against Nnitrosodiethylamine- induced liver injury in rats .Food.Chem.Toxicol., 50: 2027-2033.

Kujawska, M.; Ignatowicz, E.; Murias, M.; Ewertowska, M.; Mikołajczyk, K. and Jodynis-Liebert, J. (2009): Protective effect of red beetroot against carbon tetrachloride- and $\mathrm{N}$ nitrosodiethylamine-induced oxidative stress in rats. J. Agric. Food Chem., 57: 2570-2575.

Kujawska, M.; Ignatowicz.E.; Murias, M.; Ewertowska, M.; Mikolajczyk, K. and Jodynis-Liebert,J.(2009):Protective effect of red beetroot against carbon tetrachloride and $\mathrm{N}$ nitrosodiethylamine- induced oxidative stress in rats .J.Agri.Food Chem., 57:2570-2575.

Kumar, S.P.; Bhaumik, A.; Chopra, M. and Neelima-Devil, K. (2016): Evaluation of Anti diabetic activity of Ethanolic Extract of Beet Root (EEBT- Beta vulgaris) against Streptozocin induced diabetic Rats.Journal of Drug Discovery and Therapeutics, 4( 37):01-06.

Lee. R. and Nieman, D. (1996): Nutritional Assessment. 2 nd, Mosby, Missouri, USA.

Lipinski, B. (2001): Oxidative stress in diabetes Mellitus. Diabetes Complications, 15(4):203-210.

Lopez-Virella, M.F. (1977): High density lipoprotein cholesterol by selective precipitin. Clin chem., 23: 882.

Lundberg, J.O.; Carlstrom, M.; Larsen, F.J. and Weitzberg, E. (2011): Roles of dietary inorganic nitrate in cardiovascular health and disease. Cardiovascular Research, 89(3):525-532.

Machha, A. and Schechter, A. N. (2011): Dietary nitrite and nitrate: A review of potentialmechanisms of cardiovascular benefits. European Journal of Nutrition, 50: 293-303. 
Malhotra, V.K. (2003):"Practical Biochemistry for Students" Fourth edition, Jaypee Brothers Medical Publishers (P) LTD, New Delhi.

Maritim, A.C.; Sanders, R.A. and Watkins, J.B. (2003): Diabetes, oxidativestress, and antioxidants: a review. J. Biochem. Mol. Toxicol. 17 (1), 24-38.

Miraj, S. (2016): Chemistry and pharmacological effect of beta vulgaris: A systematicreview. Der. Pharmacia. Lettre, 8:404-409.

Moss, D. W. and Henderson A.R (1999): Clinical enzymology. in: Burtis CA, Ashwood, E.R., editors. Tietz textbook of clinical chemistry. 3rd ed. Philadephia: WB Saunders company; P. 617721.

Ninfali, P.and Angelino, D. (2013): Nutritional and functional potential of Beta Vulgaris cicla and rubra. Fitoterapia, 89:188-199.

Nisa, A.; Saeed, K.; Hina, S.; Zahra, N.; Mazhar, S.; Kalim, I. and Syed, Q. (2015): Nutritional, antioxidant, microbiological and toxicological studied on red dye extracted from red beet roots (Beta Vulgaris), Res.J.Chem.Sci., 5(4):1-6.

Oliveria, G.V.; Morgado, M.; Pierucci, A.P. and Alvares., T.S. (2016): Asingle dose of beetroot-based nutritional gel improves endothelial function in the elderly with cardiovascular risk factors .Journal of Functional Foods.,26:301-308.

Olumese, F.E. and Oboh, H.A.(2016): Effects of Daily Intake of Beetroot Juice on Blood Glucose and Hormones in Young Healthy Subjects.Nig. Qt J. Hosp. Med., 26(2) :455-462.

Pamela, C.C.; Richard, A.H. and Denise, R.F. (2005): Lippincott's Illustrated Reviews: Biochemistry, $3^{\text {rd }}$ Edition. Lippincott Williams and Wilkins, Baltimore, MD.

Panghal, A.; Virkar,K.; Kumar, V., Dhull, S. B., Gat, Y. and Chhikara, N. (2017):Development of probiotic beetroot drink. Current Research in Nutrition and Food Science Journal, 5: 168174. 
Pham-Huy, L.; He, H. and Pham-Huy, C. (2008): Free radicals, antioxidants in disease and health. IJBS., 4(2):89-96.

Račkauskiene, I.; Pukalskas, A.; Venskutonis, P. R.; Fiore, A.; Troise, A. D. and Fogliano, V. (2015): Effects of beetroot (Beta vulgaris) preparations on the Maillard reactionproducts in milk and meat-protein model systems. Food Research International, 70:31-39.

Rojas, E.; Herrera, A.L.; Poirier, L.A. and Ostrosky - Wegman, P. (1999): Are metals dietary carcinogens? Mutat. Res., 44: 157 - 181. E.

Sansbury, B.E. and Hill, B.G. (2014): Regulation of obesity and insulin resistance by nitric oxide. Free Radical Biology and Medicine, 73: 383-399.

Slavov, A.; Karagyozov, V.; Kratchanova , M. and Kratchanov, C. (2013): Antioxidant activity of red beet juices obtained after microwave and thermal pretreatments. Czech J. Food Sci., 31:139147.

Szaefer, H.; Krajka-Kuzniak, V.; Ignatowicz,E.; Adamska, T. and Baer-Dubowska, W.(2014):Evaluation of the effect of beetroot juice on DMBA-induced damage in liver and mammary gland of female Sprague-Dawley rats .Phytother.Res.,28:55-61.

Ullah, A.; Khan, A. and Khan, I. (2015): Diabetes mellitus and oxidative stress-A concise review. Saudi Pharmaceutical, 24(5):547-553.

Vulić, J.J.; Ćebović, T.N.; Čanadanović-Brunet, J.M.; Ćetković, G.S.; Čanadanović, V.M.; Djilas, S.M. and TumbasŠaponjac, V.T (2014): In vivo and in vitro antioxidant effects of beetroot pomace extracts. J. Funct. Foods, 6:168-175.

World Health Organization (2010): Global status report on noncommunicable diseases, Geneva, Switzerland. 


\section{Wafaa A. Refaat and Doaa E. El-Nassag}

Wotten - Beard, P. and Ryan, L. (2011): Short communications a beetroot juice shot is a significant and convenient source of bio accessible antioxidants, Journal of Functional foods, 3(4):329-334. 


\section{Wafaa A. Refaat and Doaa E. El-Nassag}

\section{النشاط المضاد للأكسدة لمسحوق جذور البنجر في الفئران المصابة}

\section{بمرض السكر المستحث بواسطة الألوكسان}

وفاء أحمد رفعت1 ، دعاء السيد النساج 2

1قسم التغذية وعلوم الأطعمة ـ كلية الاقتصادالمنزلي ـ جامعة المنوفية- مصر

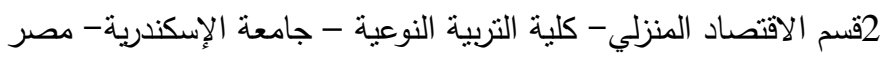

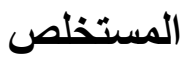

مرض السكري (DM) هو واحد من أخطر الأمراض التي تؤثر على صحة الإنسان ؛

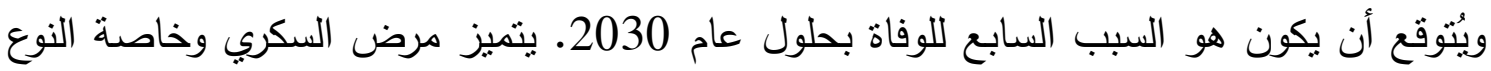

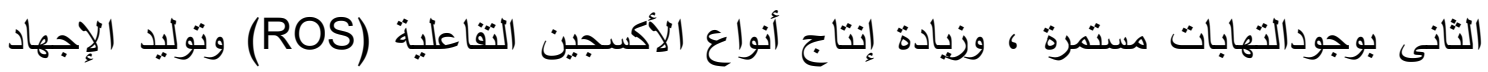

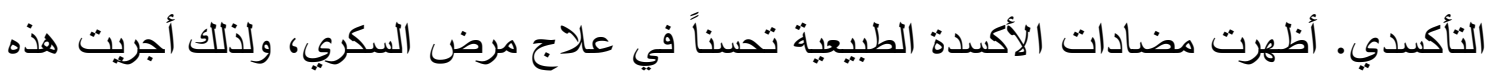

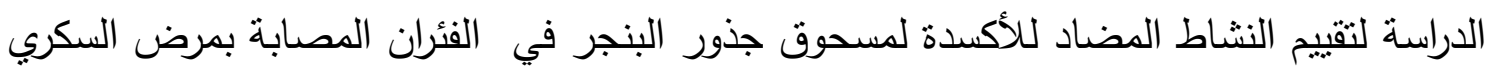

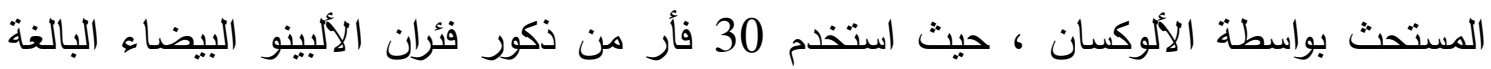

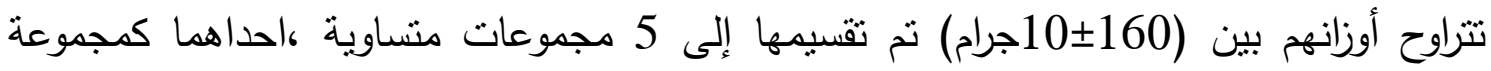

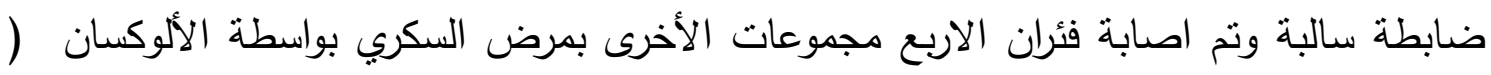

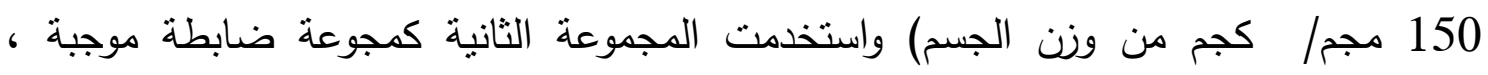

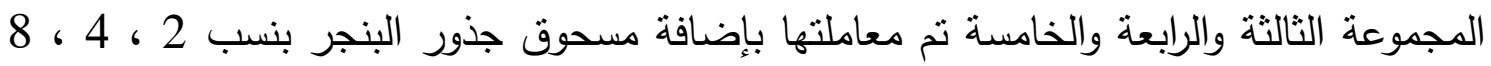

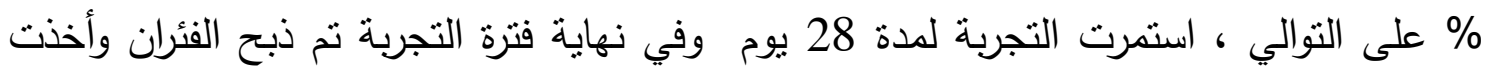

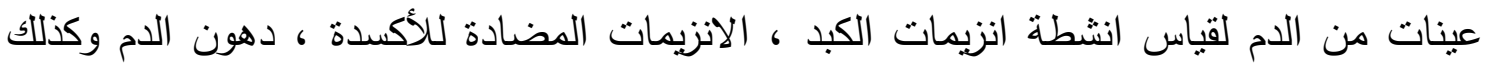

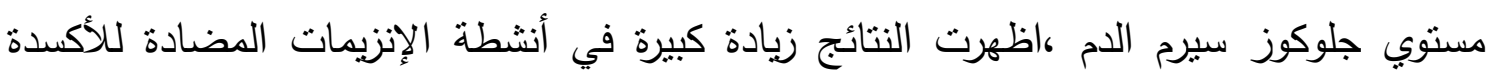

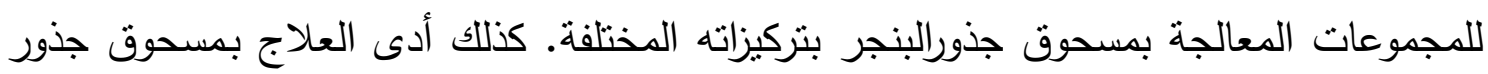

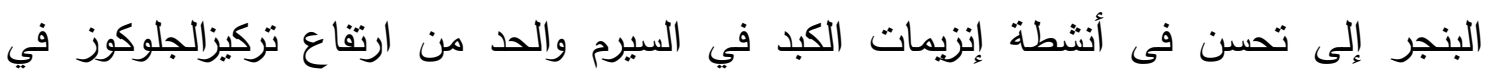

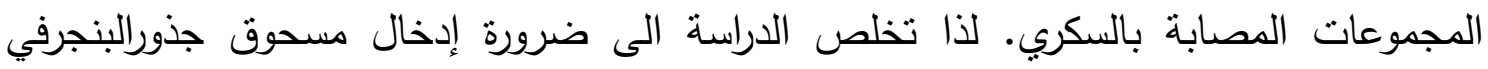

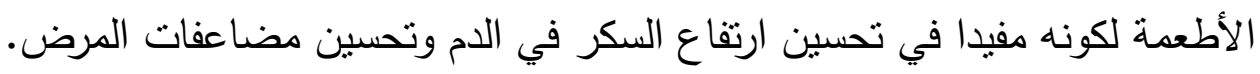

الكلمات المفتاحية: مرض السكرى، ارتفاع جلوكوز الدم، جذور البنجر، صورة دهون الدم ، أنزيمات الكبد، الانزيمات المضادة للأكسدة. 